\title{
Evaluative system design applied to transidiciplinary projects as a tool for the terminal efficiency increment
}

\section{Diseño de sistema evaluativo aplicado a proyectos transdisciplinarios como herramienta para el incremento de la eficiencia terminal}

TOVAR-ROSAS, Claudia Rocio †*, GARZA-MOYA, Luis Roberto, ARREOLA-BURCIAGA, Josué Mizraim and DELGADILLO-ALVARADO, Jessica Astridt

Universidad Politécnica de Gómez Palacio, Information Technology Engineering

ID $1^{\text {st }}$ Author: Claudia Rocio, Tovar-Rosas / ORC ID: 0000-0002-8238-7493, CVU CONACYT ID: 745074

ID $1^{\text {st }}$ Co-author: Luis Roberto, Garza-Moya / ORC ID: 0000-0002-5740-1476, CVU CONACYT ID: 68866

ID $2^{\text {nd }}$ Co-author: Josué Mizraim, Arreola-Burciaga / ORC ID: 0000-0002-2722-1386, CVU CONACYT ID: 769055

ID $3^{\text {rd }}$ Co-author: Jessica Astridt, Delgadillo-Alvarado / ORC ID: 0000-0003-3197-5188, CVU CONACYT ID: 572720

DOI: $10.35429 /$ JET.2024.5.13.28.33

Received: March 25, 2020; Accepted June 19, 2020

\begin{abstract}
The objective of this article is to show the design of an evaluative scheme that begins with the creation of Transdisciplinary projects, applied in students from the currently bachelor's degrees inside the Universidad Politécnica de Gómez Palacio. The projects that are counted into the Transdisciplinary, tend to relate agents from different specialties, with the main purpose of unite the knowledge and abilities in the creation of a complete integrating project, supported by diverse members of the team. The Transdisciplinary gives the disciplinary or methodological part the students learn in the classroom, meanwhile the transversally only unites the concepts among the environment where they are, characteristics like ages, sex, among others, this is why this Project emphasizes the discipliner part of the classroom. The way the design is created, sets off from the results obtained from the surveys applied to the eighth four-month period students; besides evaluates the former students from the generation $2014-2017$. Once the results are obtained, the next step is to create a new evaluation methodology and with it, it is expected to create a change in the evaluation system in the Superior Educative Institutions.
\end{abstract}

Terminal Efficency, Evaluation, Transdisciplinarity

\begin{abstract}
Resumen
El objetivo del presente artículo es presentar el diseño de un esquema evaluativo que parte de la creación de proyectos transdisciplinarios, aplicado en alumnos de las carreras existentes en la Universidad Politécnica de Gómez Palacio. Los proyectos que aplican transdisciplinariedad, tienden a relacionar agentes de diversas especialidades, con el fin de unir los conocimientos y habilidades en la creación de un proyecto integrador completo, apoyado por los diversos integrantes del equipo. La transdisciplinariedad aporta la parte de disciplinaria o metodológica que se ve en el aula de clases, mientras que la transversalidad únicamente une estos conceptos junto al entorno en el que estén, características como edades, sexo, entre otras, por ello este proyecto hace énfasis en la parte disciplinar del aula. La forma en la cual es creado el diseño, parte de los resultados obtenidos en la aplicación de encuestas realizadas hacia los alumnos en el grado de octavo cuatrimestre; además de evaluar a partir del seguimiento de egresados de la generación 2014 2017. Una vez obtenidos los resultados se pasará a crear una nueva metodología de evaluación y con ello se pretende crear una propuesta de cambio en el sistema de evaluación en las Instituciones de Educación Superior (IES).
\end{abstract}

Eficiencia terminal, Evaluación, Transdisciplinariedad

Citation: TOVAR-ROSAS, Claudia Rocio, GARZA-MOYA, Luis Roberto, ARREOLA-BURCIAGA, Josué Mizraim and DELGADILLO-ALVARADO, Jessica Astridt. Evaluative system design applied to transidiciplinary projects as a tool for the terminal efficiency increment. Journal Educational Theory. 2021. 5-13: 28-33

\footnotetext{
* Author Correspondence (e-mail: ctovar@upgop.edu.mx)

$\dagger$ Researcher contributing as first author.
} 


\section{Introduction}

At present, the competency-based education model called CBE is the standard that most schools, both in basic and higher education, have implemented in their institutions, whether private or public, although it is not only a new model, but it also applies the four educational skills.

This inculcates the idea that students should have the capacity to develop these competences, as well as carry out projects in conjunction with other people in order to obtain a product that is transcendental and perfectly grounded, as this increases the student's skills and from these projects they can make their first business plans.

This project is based on the detected need to design an evaluation system for integrative projects, as projects are carried out in the university but within the same careers, i.e. multidisciplinary projects and these do not manage to have a lasting impact as it is to make transdisciplinary projects, in addition to the fact that this project is carried out in order to provide a tool to increase the terminal efficiency rate, as a measure of innovative implementation in the institution in which the design of this project is put as a sample.

Currently there are some theories on which this project was based, in order to verify the relevance and possible fields of action of the present, such as the theory of transdisciplinary of Morin (2013), which arises from the union of various disciplines, aim to create a comprehensive project, which has contributions from various skills of the creators, in addition to a set of tools, which contribute to developing a comprehensive and complex project, which responds to the solution of a common problem for various places or regions, The more impact it can produce on the population at which the project is focused, the better, that is to say, transdisciplinary seeks to unite different talents from different areas for the development of a final product, such as a theory, a system, a project, among others, this is done by bringing together the different skills shown in each of those involved, being contributed in the various elements to be used, as is the case of any marketable product, in which different areas are involved for the realization of a single final product supported by the skills of each employee involved in the production process.
Another of the relevant theories for this article was the contribution of Basarab (1996), in his manifesto, that "the transdisciplinary vision proposes to consider a multidimensional reality, structured on multiple levels, which replaces the unidimensional reality of a single level in classical thinking", with this it is understood that the world has entered a stage in which it must be understood that the fact of being in a globalised world must change the meaning at the educational level, In addition, it is necessary to consider the application of new knowledge that cannot be obtained completely in the classroom, such as the possible errors and methodological solutions used in companies, as well as considering the development of the various skills and aptitudes necessary for the creation of various projects and the analysis of the different scenarios to be presented when carrying out a project in a transdisciplinary team.

A relevant point that Basarab brings to education is the mediation of students' knowledge applied in a real environment and the use of innate skills, i.e. the development of a terminal product with the collaboration of different disciplinary areas and thus achieving a collaborative and functional project.

An important task to improve in current education is the intervention of subjects that are not treated very well in the different areas of knowledge in emotional matters, which are used for the development of skills such as communication, which can be reflected in the subjects of development of organisational skills, values, among others, as well as also affecting the administrative area, with subjects such as administrative process, entrepreneurship, among others, which contribute to the student's knowledge in terms of development and improvement of the final projects to be integrated, as with this, they should have a perspective of the activities to be carried out and the way in which these processes can be improved, either by implementing new techniques for processing materials, or by having a balanced work team, with which not only can innovative products be made, but they will also have first-hand projects, as well as being able to patent prototypes and generate changes in the scientific community (Reyzabal and Sanz, 2001). 
Transversal projects tend to support not only to create collaborative work, but also have a variety of approaches depending on the project to be carried out, as indicated by the UNAM (2014), whose main theme is the approach of transdisciplinarity, from all points of view, the treatment of problems from the perspective of an engineer, doctor and accountant, can be quite different, since according to the educational background of each of them is their type of thinking and analysis they can reach when trying to solve a concise problem, it is therefore that in this meeting topics such as:

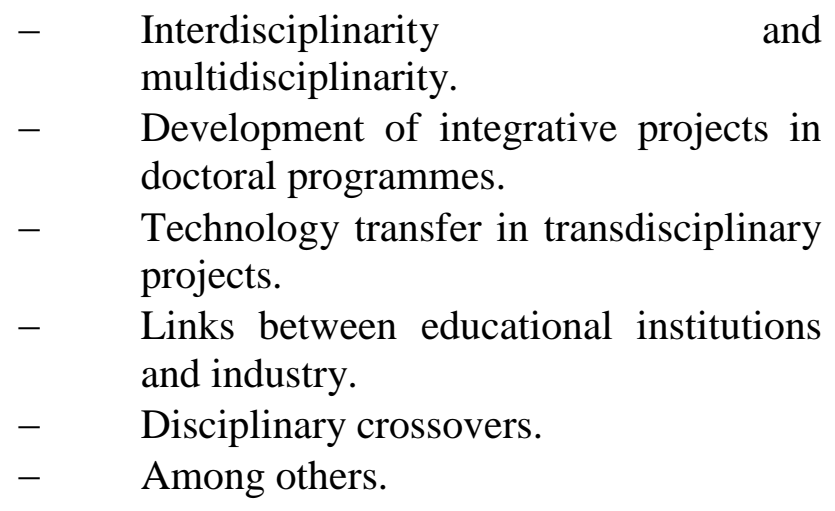

All of them emphasise the need for a radical change in the current education of higher education institutions, since these changes greatly benefit the integral development of students, as well as being a good option when developing projects at postgraduate level.

Most of the similar projects have been implemented in postgraduate or professional stays dedicated to the development of modern technologies and in which the level of professionalism and attention to detail increases, besides being able to find these same techniques in companies, since they handle different areas of development to culminate in the sale of a product, so the question arose: How can transdisciplinary projects be implemented at the undergraduate level and what would be the scope of such projects?

The terminal efficiency as mentioned by CACEI (2018) indicates that it is the "number of students who finish an educational level in a regular way (within the established ideal time)", i.e. in the ten semesters that by regulation of the Polytechnic Universities the student must graduate, in order to be taken into account as part of the terminal efficiency of the educational programme.
From the above questions arises the reason for proposing this project as a design, which is the prelude to its full implementation as a fundamental and evaluative part of the current school model.

\section{Methodology to be developed}

The first part of the implementation of this project was to bring together the teachers of the various careers at the university, who were giving classes in the eighth semester grades, the leaders of this product being the subjects relating to entrepreneurship and technology project management, in addition to having working tables in order to optimise time, each of the careers gave opinions on the types of characteristics they would like the projects to have, number of members, as well as various aspects.

As a second stage, the debate began on the standardisation of the form of student assessment, as the contribution would be dispersed due to the different profiles.

Once the form of evaluation had been defined, a manual was drawn up in which all the established agreements were set out, as shown in Table 1, a preview of the evaluation and monitoring model for transversal projects.

\begin{tabular}{|l|l|l|l|l|}
\hline \multicolumn{5}{|c|}{ Formation of the idea } \\
\hline \multicolumn{2}{|c|}{ Formation of the working team } \\
\hline
\end{tabular}

Table 1 Design of the evaluation proposal. Source: Own Elaboration

The last stage was to bring the students together and also to share the knowledge of the implementation of transdisciplinary projects, thus achieving the homologation of opinions and approval for their development, as the project was directly applied in them. 
At the end of the previous stage, project proposals were requested, as well as the evaluation of their creation and implementation in real life, as some of the characteristics that the project had to have were the following:

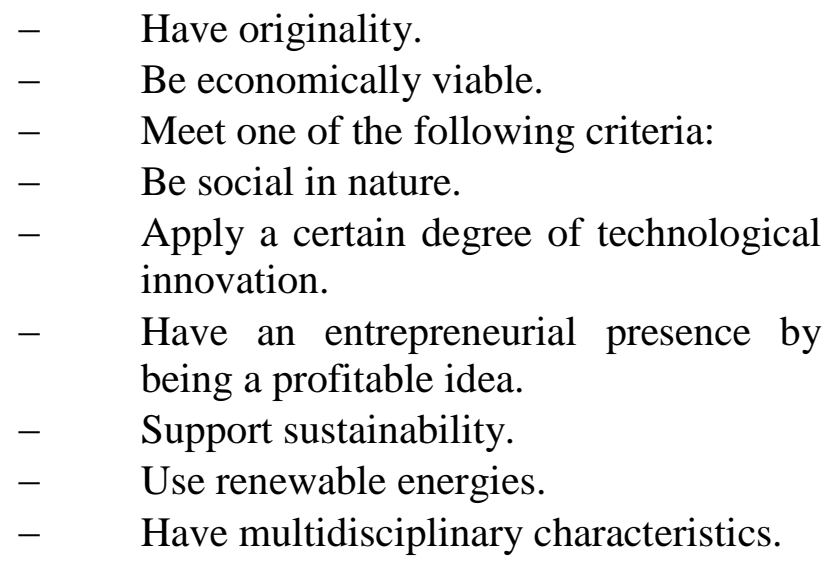

Once the step to which the project belonged was evaluated and it was corroborated that the requested characteristics were met, we proceeded to implement the structural design of the project, which must be developed in four months and have the specifications suggested above, since at the end of the same we proceeded to carry out a contest, which lasts one day, as time to expose your project to judges and get recommendations, in addition to support to incubate the project idea.

The knowledge and skills that the students provided in the development of the project were especially essential, since the Bachelor's Degree in International Business (LNI) provided the methodological contribution of sales, as well as the type of trade to be implemented, initial investment, among others.

On the part of the degree course in Information Technology Engineering, the creation of a commercial prototype in some cases and in others the creation of a website for sales and promotion of the articles, as a contribution from the degree course in Manufacturing Technology Engineering, the creation of manufactured products and even models of the materials used was carried out.

An important part developed by the Biotechnology Engineering course was the management of waste and the use of some substances that could affect the users.
As an implementation by the Animation and Visual Effects Engineering course, the creation of simulations of possible scenarios for the implementation of the product was fundamental in explaining prototypes that in real size would be too large or whose production cost would be too ostentatious.

As a culmination of the projects, their effectiveness was evaluated in the years following their implementation, obtaining as a result an increase in completion rates (Graph 1), which shows the increase in the number of students graduating from the various degree courses, since in the years prior to their implementation the number of graduates was low, In the years prior to its implementation, the number of graduates was low, since 3 out of every 10 students who entered each of the specialisations completed their degrees within the time specified by the General Coordination of Technological and Polytechnic Universities (CGUTyP), which is why, on observing an increase in terminal efficiency, the impact of this methodology on students' terminal education was assessed.

The impact that has been obtained until the creation of the design and the relevant tests is that more than $70 \%$ of the graduates manage to get their first job in the first three months (Graph 2), these data were acquired as part of the follow-up of graduates carried out annually, in which the graduates indicate their employment situation, salary, sector to which they belong, among others, apart from as can be seen in (Graph 3) most of the graduates have a salary of more than $\$ 8,000$. 00 which is a standard for most engineering graduates in local universities and this is achieved in the first years after graduation (one to five years).

One of the advantages offered is the recognition of the knowledge learnt in the classroom, which makes several graduates request students in the last training cycles to work with them, since the knowledge obtained in the classroom and skills such as working under pressure, being proactive and working with transdisciplinary teams are part of their training and therefore they do not have to obtain any special training or even have difficulties in collaborating with other areas in the company. 
Terminal efficiency in last training cycle

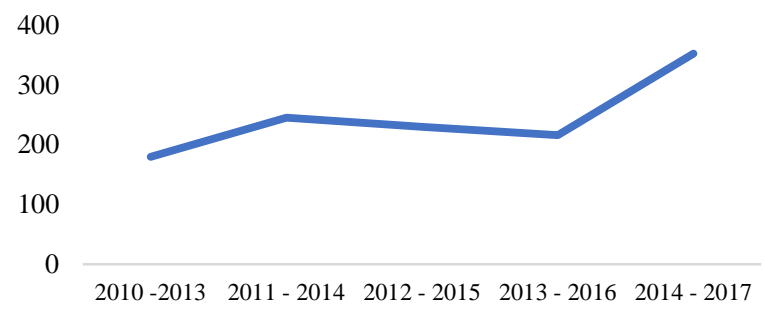

Generations

Graph 1 Completion rate

Source: Own Elaboration

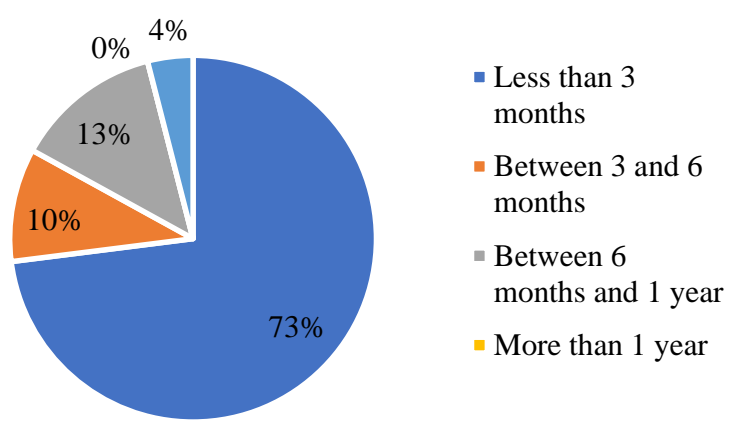

Graph 2 Time to find first job

Source: Follow-up of graduates from the UPGOP's department of liaison

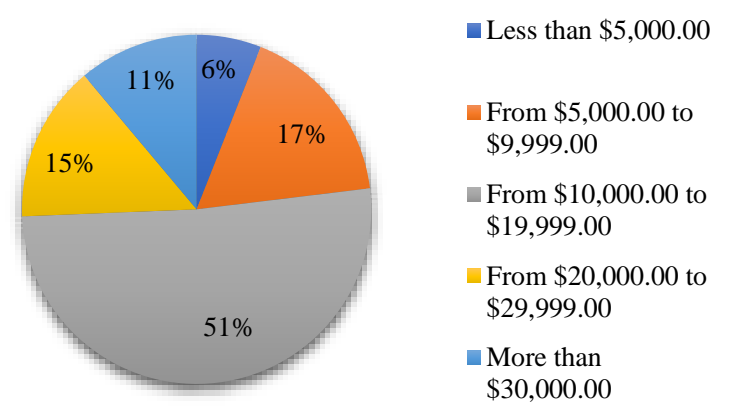

Graph 3 Detail of salaries obtained by graduates in the first years after graduation

\section{Results}

The implementation of these projects provided a reliable tool, as it was evaluated once the first test was implemented with a Cron Bach Alpha, this as a method for validation and thus have a tool that supports the terminal efficiency, since students to enter into this scheme had a reliable and adaptable option to the needs of the various subjects that they take in that term, The project is implemented in the eighth year of the school year, with the aim of providing the students with a real environment such as the one they will find in a company.
The project is implemented in the eighth semester due to certain characteristics of the students, such as:

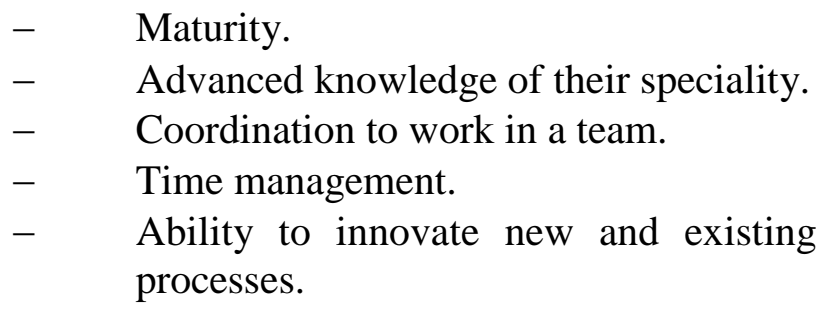

\section{Discussion}

Through the implementation of the project design, it was possible to delve into the criteria used in such projects, such as what is theoretically known as transdisciplinarity and its application in integrative projects, as well as using methodologies suggested in postgraduate courses and student exchange stays abroad.

\section{Acknowledgements}

In the first instance, special thanks go to the students who were actively developing the projects, as well as the UPGOP teachers, who actively supported the students and evaluated the various deliverables. Another special thanks goes to the Polytechnic University of Gomez Palacio, for the support given and for providing the necessary space for the development of this project.

Special thanks also to the judges who actively supported the students by giving recommendations and possible improvements to the projects carried out by the students.

\section{Conclusions}

The present project culminated in the creation of a transdisciplinary project design, which was applied to eighth semester students of the generation of 2014 - 2017, this was a sample test, with which it is intended to modify the model to be implemented, as well as increase the characteristics of this project, in order to make a model of education and modify some gaps that are in the current education system.

In addition, a reliable source of measuring the skills developed by this type of project was obtained. 
Another of the advantages obtained was the increase in the retention of the school curriculum, as well as the increase in the terminal efficiency, since there was a high deficiency in terms of the completion of engineering studies, which is why finding the advantages of the implementation of this design is expected to increase the number of graduates of the various specialties.

\section{References}

Basarab Nicolescu. (1996). La transdisciplinariedad manifiesto. Paris: 7 Saberes.

CACEI (2018). Marco de referencia para la acreditación de los programas de ingeniería (versión 2018). México: Consejo de Acreditación de Enseñanza de la Ingeniería, A.C.

Morin, E. (2013). Edgar Morin Multiversidad. Recuperado el 12 de 03 de 2018, de Multiversidad:

http://edgarmorinmultiversidad.org/index.php/q ue-es-transdisciplinariedad.html

Reyzabal, M. V., \& Sanz, A. I. (2001). Los ejes transversales, aprendizajes para la vida. Secretaria de Educación Pública, 420-435. Retrieved from http://www.dgespe.sep.gob.mx/public/genero/P DF/GEN\%20O1/G_01_16_Los\%20ejes\%20tra nsversales.pdf

UNAM. (2014). Encuentro sobre proyectos transdisciplinarios: Investigación, formación y gestión. (U. C. 02, Ed.) 